\title{
pÿResistance to development amongst the Kogui of the Sierra Nevada de Santa Marta
}

\section{Pyhälä, Aili}

Routledge, Taylor \& Francis

2020-07-10

pÿPyhälä , A 2020 , Resistance to development amongst the Kogui of the Sierra Nevada de Santa Marta . in R Colbourne \& R B Anderson (eds), Indigenous Wellbeing and Enterprise :

Self- Determination and Sustainable Economic Development . Routledge, Taylor \& Francis .

$<$

https://www.routledge.com/Indigenous-Wellbeing-and-Enterprise-Self-Determination-and-Sustainable/Colbourne-An $>$

http://hdl.handle.net/10138/332348

acceptedVersion

Downloaded from Helda, University of Helsinki institutional repository.

This is an electronic reprint of the original article.

This reprint may differ from the original in pagination and typographic detail.

Please cite the original version. 


\title{
3 Resistance to 'development' amongst the Kogui of the Sierra Nevada de Santa Marta
}

\author{
Aili Pyhälä
}

\section{Introduction}

Having worked with Indigenous peoples and local communities on five continents, rarely have I come across societies that have not already been (or are in the rapid process of being) lured into the mainstream mode of what I in this chapter refer to as "development" - the (often false) notion of progress and civilization that, on the one hand, sees Western cultures as somehow "better" and, on the other, sees humans and nature as somehow separate from one another (Gudynas, 2017). Having witnessed such processes of separation and estrangement across the globe, I have grown increasingly preoccupied about the (often manipulative) promotion (and even imposition) of supposedly more "advanced" or more "effective" programs of education, healthcare, food security, and even nature conservation, and the long-lasting impacts that such interventions have on local human and non-human wellbeing. Sadly, most Indigenous peoples that come into sustained contact with the Western world end up to a large extent being acculturated, whether through religious conversion, Western healthcare and education, dress, food, alcohol, television, or cell phones - in the process losing their own wealth of traditional local knowledge, culture, and identity. This loss of traditional knowledge and culture is detrimental not only to the wellbeing of the knowledge holders themselves and their descendants (Berkes, 1999; Johnson et al., 2016), but to global humanity as a whole - seeing that we, too, in the WEIRD (Western, educated, industrialized, rich, and developed) (Heinrich, 2010) world have a great deal to learn (or perhaps remember) from Indigenous knowledge and practices.

The Kogui are an exemplary case demonstrating long-held resistance and resilience in the face of decades of external pressures and failed external attempts of elimination and assimilation. To this day, despite increased contact and acculturation, the Kogui continue to maintain and strongly safeguard their culture, traditions, and identity, with very limited interaction with people other than their fellow Indigenous peoples of the Sierra Nevada. That said, the extent of multiple forms of externally driven economic development and the impacts this is having on Kogui territory, livelihood, and wellbeing is of great concern. The tensions that this scenario creates between an ancient culture - that of 
the Kogui, who stand strong in their self-determined lifeway and identity and the capitalist ventures of many non-Indigenous stakeholders seeing the wealth of resources and opportunities in the area are well worth examining and questioning.

I was drawn to the Kogui already several years ago, when I first saw portraits of Kogui men and women in Antonio Briceño's stunning photographic collection entitled "Gods of America" (2007). There was something about their mesmerizing gaze that simply captivated me. Similarly, I could see that their traditional dress - in all-white cotton - was not something just for show for tourists passing by. There was something very strongly rooted and genuine in how the Kogui presented themselves in these photos. Some years later, while conversing with another friend, this time a hikuri healer who had also spent some days with the Kogui, I learned of the extraordinary apprenticeship training required to become a mamo - the highest spiritual authority amongst the Kogui - and how strongly Kogui livelihood is defined and guided by their fundamentally nature-based cosmovision (From the Heart of the World, 1990; Aluna, 2011). This unique case in today's globalized world - demonstrating ecological sustainability coupled with still-held resistance to the outside (despite contact and access) - was what led me to try to speak with the Kogui.

I finally did have the immense fortune and honor to spend one month in and around the Sierra Nevada de Santa Marta, the ancestral territory of the Kogui, in March-April 2018. With such a short field visit, I do not by any means claim or pretend to be an expert on the Kogui, and am very grateful to all those fellow scholars (many of whom are referenced below) who have produced both literary and audio-visual documentation that has served me substantially whilst carrying out and writing up my own research (see, for instance, Arbeláez Albornoz, 1994; Ereira, 1992; Orrantia, 2002; Ortiz Ricaurte, 2004; Reichel-Dolmatoff, 1950, 1976, 1982, 1987; RodriguezNavarro, 2000; Uribe, 1998).

This chapter draws on data from two visits, the first collected during my one-month field visit in March-April 2018, during which I carried out a handful of interviews and focus groups with Kogui and other Indigenous representatives in the city of Santa Marta as well as in various parts of the Sierra Nevada and Tayrona National Park. I had the opportunity to stay in two Kogui communities (La Ciudad Perdida and Tungueka), in both of which I interviewed the leaders, elders and mamos. I also interviewed relevant nonIndigenous NGO representatives in Bogota and Santa Marta. The second visit took place in November 2018, when I had the honor of spending some days with the Cabildo Governador (political leader) of the Kogui, and met again with representatives at the Organisación Gonawindua Tayrona (OGT), the principal political body officially representing the four Indigenous peoples of Sierra Nevada de Santa Marta. On this second visit I also undertook a long interview with the director of the Sierra Nevada National Park, who has been working closely with the Kogui for many years. I am intentionally withholding the names of all the interviewees in order to respect their rights to anonymity. 
In this chapter, I present some preliminary findings on where the Kogui see themselves vis-à-vis Western notions and impositions of "development", highlighting both the challenges and alternatives currently faced by Kogui communities in being able to practice their own self-determined path and lifeways. Inspired by other similar works (Altman and Kerins, 2012; de la Cadena, 2011; and Kohn, 2013), I examine also the beliefs and relationships that the Kogui have of and with the natural world and non-human species - a cosmovision that goes far in explaining the Kogui worldview vis-à-vis development. I want to underscore that in speaking of Kogui (or other Indigenous) resistance, I am not referring only to straightforward means of opposition or activism, but rather, the "fine-tuned and subtle practices of resistance [that] hold more relevance and currency in today's biopolitical world" (Lindrooth and Sinevaara-Niskanen, 2015: p. 13), hence also of resistance to assimilation of various forms.

The layout of this chapter is as follows. First, I give a brief introduction to the Kogui and their ancestral territory, laying out a context both in terms of historical processes and attempts of colonization, as well as current territorial rights. I then examine the processes and impacts of the most prominent development interventions and impositions in the area, namely multiple forms of encroachment, extractivism and land-grabbing, as well as attempts at assimilation (including through education, evangelization, and healthcare) and finally tourism. All of these are what external actors would probably refer to as contributors to "economic development". In contrast, I question and share what the Kogui have to say about development, and examine what rights they have for claiming their own alternative pathways. I end the chapter with some conclusions and policy recommendations that I hope will help guide any external efforts to support and promote the socio-environmental rights and sustainable self-determination (see Corntassel, 2008; Corntassel and Bryce, 2012) of not only the Kogui, but also of other Indigenous peoples of the Sierra Nevada and beyond.

\section{The Kogui and their ancestral territory - past and present}

The Kogui (also known as Kággaba, meaning "jaguar” in the Kogui language) are an Indigenous ethnic group living on the north-facing valleys of the Sierra Nevada de Santa Marta (SNSM). The SNSM is a coastal mountain range in the north of Colombia, with a surface area of approximately $17,000 \mathrm{~km}^{2}$. Together with the other three Indigenous peoples of the Sierra Nevada - the Arhuaco, Wiwa, and Kankuamo - the Kogui are believed to be direct descendants of the Tayrona culture, an advanced civilization well known for its intricately fabricated gold objects that goes back to at least the first century CE, flourishing before the Spanish conquest. Before the arrival of the Spanish conquistadors, the Tayrona were forced to move into the highlands when the Caribs invaded the lowlands (around $1000 \mathrm{CE}$ ). By the time the Spanish entered modern-day Colombia in the fifteenth century, the Kogui had found refuge in isolation, unlike many of the other Indigenous groups in the region who suffered dire consequences. Up 
to the present day, the Kogui have remained in the mid-highlands of the Sierra, untouched by the worst effects of colonization, modernization, and globalization, allowing them to preserve their traditional ways of life.

Like elsewhere in Colombia, the SNSM also comprises Indigenous territories referred to as resguardos. The area in which the Kogui live is officially administered as the Resguardo Kogui-Malayo-Arhuaco (RKMA), a public institution under the current political and administrative structure of the Colombian state, constituted under Resolution 0109 (from October 8, 1980). The RKMA currently has a surface area of 412,871 hectares. Like all resguardos, the RKMA is subject to land use planning based on the Western model of applying land titles, not reflecting the traditional form of land use planning or management. Similarly, the public state entities in the area promote land use planning based on privatization and commercial use (i.e., commodification) of natural resources, rather than reflecting local Indigenous norms and institutions.

Despite this official territorial assignment by the Colombian state, the Kogui claim that their ancestral territory is far more extensive than that which has been recognized under the RKMA. Indeed, OGT is working on a proposal to extend the surface area of the resguardo (pers. comm., director of OGT). This proposed extension they refer to as the territorio amplio ("the wide territory"), which is marked by the Linea Negra (i.e., the "Black Line", or Seshizha in Kogui language). Se in Kogui means the spiritual world, the invisible space; Shi means string, or the spiritual and energetic connections that unite all the sacred spaces in the territory, and all aspects of nature and humans; Shi are considered the veins interconnecting the different dimensions of the ancestral territory, much like the veins in a human body. Thus, the Linea Negra, or Seshizha, refers to the connection with the spiritual principals and the Indigenous peoples of the world (OGT, 2017). The Linea Negra forms a ring connecting all the sacred sites extending from the Caribbean coast all the way up to the highest peaks of the Sierra Nevada, covering all the valleys from the River Ranchería all the way to the River Aracataca. According to the Kogui, the Linea Negra demarcates their ancestral space and jurisdiction, that which contains all the sacred spaces and sites that connect, weave, embody, and secure the body of the Mother - from the base of the river basins, from the sea to the snowy peaks, and from each person to the infinite universe - and it is according to these connections that life in the Sierra is maintained, according to the Law of Origin (OGT, 2017; Witte, 2018). This area, according to the Kogui, is the territory that the Mother of Origin left to them and the other three Indigenous peoples of the SNSM, for them to carry out their mission in caring for nature. As one interviewed Kogui representative clarified: "The Línea Negra is all ancestral territory. No one has the right to take this away, not even if the national government changes."

The recognition and care given to sacred sites is fundamental to the Kogui. The four principal sacred sites are the ezuama; each is represented by one of the four main rivers descending from the highest peak of the Sierra Nevada. In addition, the Kogui ancestral territory is scattered with sacred sites, gaka, all the way from the coast up to the highest peaks, including mangroves, estuaries, even 
sites in the sea itself. The Kogui believe that if the sacred sites are destroyed, the balance between spiritual and material as well as the connections between the different components of the territory are altered, as is the possibility to continue the cultural work. Traditionally, the Kogui would make pilgrimages to these sacred sites to leave offerings. There are sacred sites to prevent, cure and pay for illnesses, others where confessions are made, others where problems are solved, others for governance and decision-making.

In the SNSM, there are approximately 23,000 Kogui, across 49 communities (pers. comm., OGT). While there are also Wiwa and Arhuaco communities in the RKMA, the territory was originally inhabited only by the Kogui (pers. comm., OGT). The Kogui welcomed the Wiwa and Arhuaco onto their land when the latter two ethnic groups fled their own territories due to conflicts with narco-trafficking guerrillas during the most violent times of colonization, and up until only a few decades ago. The younger Wiwa and Arhuaco generations who were born and raised in the RKMA feel it is also their land, as they and their children have been raised there in close relations with each other and the Kogui (pers. comm., Wiwa youth).

The four Indigenous peoples of the SNSM, while each speaking a different language, see themselves as coming from the same origin and having the same spiritual Fathers and Mothers that today guide them in their norms and care for the earth and nature and all its elements. The Kogui, together with the Arhuaco, Wiwa, and Kankuamo, believe themselves to be the Older Sons of the spiritual Mother, who gave them their territory to care for as custodians. For them, to be the Older Brothers implies great responsibility. Today, these four Indigenous peoples co-inhabit the Sierra, recognizing the virtue and complementarity of each other, each carrying out their separate tasks for the better of all. However, the historic process of colonization and more recent economic development encroaching on the SNSM has led to a large part of the ancestral territory being occupied by people other than the SNSM's Indigenous population. The effects of colonization ever since the Spanish invasion have resulted in the physical displacement of the Kogui and the other Indigenous peoples of the Sierra, forcing them to leave vast expanses of their ancestral territories to find refuge in ever more high and inaccessible altitudes of the Sierra Nevada. Meanwhile settlers of different origin (including foreigners to Colombia) have been establishing themselves in the low and mid-ranges of the mountains, drastically transforming the natural environment with their roads, deforestation, extensive cultivations, and livestock. In just the past five or six decades, the cultural and ecological landscape of the Sierra Nevada has seen radical changes, many of them irreversible. I explore the processes and effects of these in more detail below.

\section{Damned development interventions}

In the past 100 or so years, a multitude of different economic, social, and political interests have driven an array of different actors from around the country (and more recently from abroad) to explore and invest in business ventures in 
the Sierra Nevada, amongst them campesino farmers, entrepreneurs, and political actors. The increased access to the Sierra has attracted tomb-raiders, loggers, and extractivists of all kinds, as well as illicit cultivators of marihuana and coca for foreign export, agribusiness for cash crops (coffee, plantain, and oil palm), with ever more infrastructure built for the transport, energy, processing, and telecommunications, in turn attracting new laborers and settlements. Different development models have been imposed by a number of agents ranging from national legislation to the health and education sectors. All this has radically transformed both the physical and the socio-cultural landscape, and with that the relations both in the human and non-human realm.

This colonization has transformed not only the land and ecological harmony and connectivity that is so important to the Kogui, but also directly affected Kogui livelihoods and wellbeing. The significantly diminished surface area of their ancestral territory, along with the disturbed peace and tranquillity, the serious (including irreversible) environmental destruction, degradation of and loss of access to many of their sacred sites, and the ruptured social organization and internal governance structures have all weakened the legitimacy and recognition of the Kogui to apply their own norms and regulations.

\section{Encroachment, extractivism, and land-grabbing}

Much of Kogui ancestral land has been taken over by the state and sold to outside settlers, including foreigners, who are now (especially since the recent Colombian peace deal) flocking to these lush, productive lands to set up tourism ventures (particularly in and around Palomino) or agricultural (largely cacao and coffee) plantations. In the valley where Tungueka is located, for instance, about 350 hectares of land have been leased out by the national government to non-Indigenous campesinos for the next 12 years (pers. comm., villagers of Tungueka).

Illustrating the magnitude, complexity, and impact of encroachment, the ancestral territory of the Kogui is today superimposed upon by three departmental territorial entities, 16 local authorities, three regional corporations, two national parks, countless public institutions, and an increasing number of privately bought-up land. Each of these come with their own plans, instalments, political instruments, and economic activities, with no effective or coherent coordination, and certainly no effective dialogue with the Indigenous authorities and custodians of the territory.

Moreover, since the 1990s, the Colombian state has been incentivizing largescale development megaprojects in the Sierra Nevada, in the form mineral extraction, dams, and large-scale agriculture. Both national and international companies have been rushing in to benefit from what the area offers in terms of mining, hydropower, agroindustry, and tourism, threatening both the ecological and cultural integrity of the SNSM.

More recently, large agro-industrial complexes have come in, responsible for clear-cutting extensive areas of primary forest in the lowlands to make way 
for cash crops (e.g., banana and oil palm) grown with the use of heavy topsoildestroying machinery and pesticides, polluting the soil and water sources. The impacts of these are further exacerbated when toxins from sprayed fumigation on cash crops is carried with the wind also to the subsistence cultivation plots of the Indigenous peoples, posing serious environmental and health risks.

As if this did not already cause enough havoc, along with these extensive cultivations come the processing plants, roads, and huge infrastructure such as new ports at sea for access to international markets. In addition to direct biodiversity loss from deforestation and soil damage, the environmental impacts of these mega-projects include flooding from dams, air and water pollution, litter and waste, and reclining wetlands along the coast due to built-up infrastructure. The socio-environmental impact of these megaprojects has been to a magnitude of affecting, according to the Kogui, the entire "order of their territory and culture" (OGT, 2017), destroying entire mountains, degrading their sacred sites, breaking ancient paths and structures, and disrupting also the social connectivity and relation to the territory.

In addition to the above, one of the most violent forms of encroachment has been that of tomb-raiding. Raiders open up tombs in identified sacred sites in search of precious gold artefacts (including remnant pieces from the ancient Tayrona culture), ripping straight into the heart of Kogui history. The Kogui, in turn, claim that this rampage has caused damage to not only their concept and sense of identity and their patrimony, but has destroyed their living knowledge. When the colonizers entered the Kogui ancestral territory they removed almost the entirety of gold and precious stones found in the sacred sites. While for people from Western cultures and for the national government such pieces of gold and precious stones may primarily be of monetary value, to be deposited into museums to attract tourism and further wealth to the country, for the Kogui and other Indigenous peoples of the Sierra, these cultural artefacts represent so much more. They are a guarantee to health, sustainable management of the territory, social organization, governance, and cultural permanence (OGT, 2017). The damage done (i.e., the removal of pieces from their particular sacred sites) is irreversible, and the Kogui see that this raiding has been the cause of many other illnesses, conflicts, and natural disasters that have followed, as the connection between social and natural elements was broken.

There are also signs of remnant trauma from the past, from threats of armed conflict in the area. Some Kogui, especially the elders who lived through the conflict only some decades ago, are still scared of coming down from the mountain, with memories of a recent past when the guerrilla would violate the women who stayed alone in the villages while the men went down the mountain (e.g., to visit sacred sites or sell/buy products) (pers. comm., Mamo Romualdo). Many Kogui stopped going on these spiritual pilgrimages to distant sacred sites, a burden that has been psychologically very hard to accept and overcome.

All these threats and invasions are resulting in less land for the Kogui, with some Kogui communities already starting to face food shortages (pers. comm., director of OGT). For instance, the natural pastures up in the higher altitudes of 
the Sierra - which have traditionally been harvested for hay (for roof construction) - are being invaded and consumed by livestock brought in by outsiders. One interviewee shared their concern of the Sierra being increasingly accessible. The mamos fear that outsiders will soon be able to reach even the most revered and protected sacred sites of the Sierra that have to date been so hard to reach that they have been left alone.

\section{Attempted assimilation}

Over the decades, there have been numerous attempts, some more direct than others, to assimilate the Kogui into mainstream society. Since the establishment of its constitution of 1890, the Colombian state put in place policies to absorb all Indigenous peoples into the Colombian society by use of Catholic missionaries and through the imposition of the national judicial system. A large part of the evangelization mission was to impose a different learning system (i.e., Western education), in a non-native language (Spanish), and to change into Spanish the previously Indigenous names of people and communities - in so doing attempting to erase the relationship that the Kogui have with their tradition, culture, and territory. The legacies of these impositions are still strongly visible in the present day, one of the greatest impacts being the weakened system of internal social organization of the Kogui. For instance, the imposition of new forms of law and ownership, including that of private property, has had its impacts on the traditional sacred valuing of the earth and the strength of the sense of the collective that has traditionally persisted amongst the Kogui (OGT, 2017). This has further weakened the traditional governance structure, social and territorial order, and management of sacred sites and their connections across the ancestral territory.

Other significant forms of assimilation are the Western systems of education and healthcare in and of themselves. Education is entirely voluntary, never forced upon a Kogui child. Kogui children are still today given by their elders the option of whether or not they want to go to school. "Schooling is not for everybody. Not all children want to go to school or learn the Western way, and they should be given the option of staying in their village and living their traditional livelihood if they want" was the view of one interviewee of mixed Kogui-Wiwa descendant. Until not long ago, only half of Kogui children were choosing to attend school, the other half choosing to stay in the village. Nowadays, while there are no exact figures, the estimate is somewhere closer to $80 \%$ of children choosing to go to school, and only $20 \%$ of children opting to stay in the village to learn the traditional lifeways (pers. comm., representative at OGT).

Few Kogui villages have a school, and those that do only have schooling at primary level. For those Kogui children choosing to continue up to secondary level, they go to one of the five boarding schools located along the foothills the Sierra. Mostly it is the boys who choose to attend school, girls more often opting to stay at home to help their mothers and elder sisters in household chores. This trend was reinforced during my stay in Tungueka, where 
I observed some two-dozen children in the local primary school, all boys. This raises the question of what implications this highly skewed attendance has in terms of gendered knowledge and cultural transmission, and how this might affect gender roles more widely in the Kogui society. With boys going to school (and perhaps after graduation going to the city in search of employment), they leave behind their traditional male-role duties - i.e., physical labor in the fields and weaving cotton and clothes. Unfortunately, I did not get an opportunity during this visit to ask the women in the village how they feel about this, but this is certainly something worth looking into.

Currently, the schooling model and curriculum offered to the Kogui is based on the Western education system and provided mostly in Spanish. According to one interviewee, the Ministry of Education long refused to understand and accept the needs of the Kogui, and to acknowledge the challenges and dilemmas they face in having their children attend school, and the implications this would have on their traditional livelihood, local knowledge, and culture. Finally, after many dialogues, and hearing and noticing time and time again that most Kogui youth really are not interested in leaving behind their own culture and moving to the city, the Ministry of Education has come to understand that it too needs to be more flexible and respectful in terms of the kinds of schooling and learning options offered to Kogui children (pers. comm., Kogui interviewee). The Ministry of Education has now accepted a Kogui-proposed project that takes mamos to visit schools in different Kogui communities to share "their explanations of how things are" (Kogui interviewee). While this is better than nothing, much more is needed in terms of substantially integrating traditional knowledge into the education system, and care needs to be taken to take into account the social, situated, and dynamic nature of that knowledge, as McCarter and colleagues (2014) suggest.

Similarly, the healthcare centres in Santa Marta and surroundings are run entirely in Spanish and by non-Indigenous practitioners. There are, to date, no Kogui doctors in the official established healthcare system in the area, meaning that there is also no healthcare (other than that provided by a few nurses or health promoters with very basic first-aid skills) offered in the Kogui language. This results in a serious limitation, posing a huge barrier especially to those Kogui (the more than 99\%) who do not speak Spanish. Furthermore, the introduction of basic clinics offering purely Western-based pharmaceutical drugs in some of the Kogui communities in the lowlands poses serious threats of the elimination of traditional knowledge of medicinal plants and healing. The impacts of these forms of assimilation, particularly education and healthcare, are taking a heavy toll on what still remains of the traditional knowledge and practices of the Kogui.

\section{Tourism}

The Sierra Nevada de Santa Marta is an important ecological zone, seeing that the mountain range comprises $70 \%$ of the Caribbean forests of Colombia. Encompassing some $17,000 \mathrm{~km}^{2}$, this isolated mountain range rises from the coast 


\section{Aili Pyhälä}

at sea level all the way to altitudes of 5,700 meters above sea level. With the combination of lush forest, waterfalls, stunning beaches, and snowy peaks, and the fascinating cultural heritage of the Tayrona, it is no surprise that the area is attracting a rapidly growing number of tourists every year. Today, tourism in the resguardo is officially allowed only in the Tayrona National Park (TNP) and on the Lost City Trek tour, both of which are hugely popular destinations amongst both foreigners and national tourists alike. All the remaining land is strictly forbidden to outsiders.

Both the TNP and the Lost City Trek tour are receiving a rapidly increasing number of tourists each year $(395,250$ tourists entered the TNP and more than 23,000 tourists visited the Lost City Trek in 2017), and the estimates for 2018 are closer to 30,000. With entrance fees at about 8 US dollars for the TNP, and 300 USD for the Lost City Tour trek, this amounts to an underestimated annual revenue of 3 million US dollars for the TNP and 6.9 million for the Lost City Trek. Of these millions of dollars, the Indigenous peoples get close to nothing, literally only a couple of hundred dollars per year (pers. comm., OGT), to be shared and distributed equitably. None of my informants seemed to know who receives this money or where it goes.

\section{Tayrona National Park}

The Tayrona National Park (TNP) covers approximately 8,000 hectares of land - extending from breath-taking beach coves up to forested peaks, along ancient Tayrona stone paths. OGT has been proposing to the national government that the resguardo manage the TNP, including the revenues, for it to be returned to the hands of the traditional Indigenous rights-holders. Yet the national government once again gave the next four-year concession of the park management and revenues to a private company, Aviatur, as part of a publicprivate partnership agreement. Jean Claude Bessudo, the CEO of Aviatur, has full and single-handed power over this enterprise, managing all four entries (and revenues derived thereof) into the NP. Meanwhile, OGT is so underfunded that the organization at the time of writing did not even have financial resources to pay the water and electricity bills of its offices in Santa Marta.

\section{The Lost City}

The Lost City (La Ciudad Perdida), which according to archaeologists was built in approximately $800 \mathrm{CE}$, is believed to have been home to about 2,0008,000 individuals of the Tayrona culture, before it was abandoned during the peak of violent Spanish conquest and colonization. The Lost City was then "rediscovered" to the outside world by tomb-raiders in 1972. The Kogui and other Indigenous peoples of the Sierra knew about it all along, but kept it secret, as one of their most revered sacred sites.

Tourism treks to the Lost City were opened up only relatively recently, when Ramon Gil, the then-Cabildo Gobernador, decided to allow eventually a maximum of six tourism agencies to run the trek, on the condition that 
the Indigenous peoples of the Sierra Nevada would receive $50 \%$ of benefits (pers. comm., OGT representative). Of the six private agencies currently operating the Lost City Tour trek, only one is owned by Indigenous peoples; however, even this particular agency that claims to be "Indigenous" - i.e., Wiwa Tours - does not in fact represent the Kogui and other Indigenous peoples of the Sierra, as it gives the illusion of. Wiwa Tours is a private forprofit organization run by an individual man (of mixed Wiwa and Kogui origin) who set up his own business and hired mostly Wiwa employees to work for him. Rumor says that the plan is to make the business entirely Wiwa, getting rid of and replacing with Wiwas the only four Kogui (of a total of 12) guides that were working for the agency at the time of writing. A representative from OGT shared that Wiwa Tours never consulted OGT or any other governing body or Indigenous representative organization prior to setting up or running the business - indicating a total lack of collaboration or agreement between the company and the official representative body of the Indigenous peoples of the resguardo.

\section{Who benefits?}

So, the questions remains: where is all the remaining revenue from tourism going? One speculation by an interviewed informant is that much of the money laundering is associated with the presence of the military up in the Lost City. During my visit, it was occupying a building up in the Lost City run by the Colombian Institute for Anthropology and Archeology (ICAAN), an institute supposedly carrying out research and further excavations, but no signs of such were seen - only military personnel.

Despite this huge discrepancy, the official Kogui representatives of the resguardo are not asking for their fair share from any of the income generated from tourism, nor claiming that the Indigenous peoples should be given any monetary compensation for the growing and destructive tourism. The majority of Kogui, including their official representative body, oppose tourism altogether. They want to be very clear, consistent, and firm in holding this stance, hence not ask for money from something that they fundamentally oppose. That said, if a complete halt to tourism is not reached (and that is unlikely to happen anytime in the near future, based on current trends), then, as one of the young Kogui representatives shared, the monetary revenues and compensation should rather come in the form of Kogui-owned projects rather than in cash handed out to only a handful of Kogui communities.

\section{Tourism at a debated crossroads in the SNSM}

Tourism in the SNSM, even in the Lost City and the TNP, continues to be highly contentious. The Lost City is deep within the RKMA, whilst the TNP lies within the territorio amplio of ancestral Kogui land. Currently, land titles in the TNP and the Lost City are managed by Parques, the state agency for protected 


\section{Aili Pyhälä}

areas. Parques is also proposing to extend the protected area coverage in the RKMA all the way up to the peaks of Tagna, entering the most untouched parts of Kogui territory. Meanwhile, a prominent Wiwa leader lobbying for political power and increased tourism has backing from the Colombian government and the ministry of the interior - not surprisingly, seeing that the Colombian state benefits hugely from tourism flows (pers. comm., Kogui interviewee). The national government is keen to open up tourism across the entire Sierra all the way up to the peaks. What this would mean for the Kogui communities still living in peace and isolation in the higher altitudes is seriously concerning, as it would open up access to the most sacred parts of Kogui territory: where the four sacred lakes are located, i.e., the origin of the four primary ezuamas and river valleys of the Kogui, the pillars of their governance system, the source of their water, "that where all is born", as one Kogui put it.

These speculations of political deals being negotiated behind closed doors, with the interest of opening up ancestral Kogui lands to even more tourism, is something that the majority of Kogui (officially 42 or the 40 communities) including the Cabildo Gobernador - are fiercely opposing. The few Kogui communities and leaders who have expressed their support for tourism (and who oppose the representation of OGT) shared that tourism is alright as long as it is contained in the corridors (Tayrona NP and the Lost City trek) where the tourism agencies have permission. They emphasized that only six tourism agencies have been given permission to work in the Lost City trek, and they are not going to reach the peaks. That said, another representative shared his concern, saying that tourists are increasingly entering without permit into Kogui lands also from Palomino and Rio Hacha axes, heading up the mountains. These tourists pay attractive amounts of cash to local guides who in turn then bribe Kogui leaders with alcohol.

The increasing tourism is according to several of my interviewees a source of multiple negative impacts. Tourism is bringing new diseases into the area, and exposing the less resistant Indigenous population to a number of health risks. Even a basic flu - which Westerners have developed antibodies to - can easily kill a small Kogui child up in the Sierra (pers. comm., OGT representative). Tourism is also displacing villages, contaminating water sources, and polluting the valleys with plastic and other non-biodegradable waste. The cultural impacts are perhaps the most urgent and worrying, with some very young children begging for money and candies along tourist paths. These and other negative impacts experienced from the rapidly growing tourism have resulted in the large majority of mamos openly expressing their opposition to tourism in the SNSM. According to OGT (2017), the mamos see tourism as being a continuation of colonization, commodifying the cultural landscape of their ancestral territory. What is certainly and glaringly obvious is that the Kogui (and other Indigenous peoples of the Sierra) are not currently benefitting anywhere near their fair, equitable, and agreed-upon share from the tourism revenues, with essentially all monetary benefits from tourism going into the pockets of private business. 


\section{Kogui views on - and resistance to - development}

\section{Impacts}

The multiple development interventions detailed above have had serious impacts on the environment, territory, culture, social organization, and spiritual-political governance of the Kogui, as well as on the interconnections between these. The Kogui have lost their possibility to manage according to traditional systems large parts of their ancestral territory, breaking the socio-ecological equilibrium that they had established and maintained for generations. They have lost access to many sacred sites, affecting the spatial function that these sites have in maintaining spiritual-ecological equilibrium. Nowadays, access to many sacred sites has been cut off by highways and other intrusive, destructive large-scale development projects and infrastructure. As one mamo exclaimed, there are sacred sites that are being colonized and bought up by outside investors (often foreigners), meaning that the Kogui can no longer do their sacred offerings there: "I as a mamo am concerned. In my territory, there is colonization in my sacred sites... I need help.' Indeed, the Kogui see that humanity is weakening the earth's ecology due to modern-day resource exploitation by non-Kogui societies.

The mega-projects in particular have been very destructive to the environment, polluting the earth, the rivers, and waters sources, again causing disequilibrium not only with Mother earth, but with the spirit of the universe, according to the Kogui (OGT, 2017). The canals and dams that have been built are seen to have negative impacts on many of the Indigenous peoples of the Sierra, whilst benefitting very few. The Kogui have lost their freedom to roam freely in their own ancestral territory, with increased land-grabbing by private property owners. The decades of encroachment have also brought with them conflict, violence, illicit cultivation (especially of marijuana and coca), tombraiding, and new diseases previously unknown to the Kogui.

Socio-economically, these interventions have led to what used to be an egalitarian and effectively functioning sharing economy to be replaced increasingly by an individualistic monetary economy, not only on the physical, but also spiritual, planes. Indeed, the Kogui see that one of the main sources of conflict in all these development processes has in fact been the monetization of everything. This regards both resource extraction and environmental products and services (including tourism) - processes that they see generating immense conflict at the spiritual and ideological level, contradicting their very own Law of Origin that in its essence seeks to protect and conserve the environment through a mechanism of exchange and equilibrium.

\section{Resistance}

For centuries, the Kogui and the other three Indigenous peoples of the SNSM have stayed in refuge in the highlands of the mountain, defending their culture, and resisting invasion by colonizers and armed forces. Despite the magnitude 
of encroachment, continued colonization, and attempted assimilation depicted above, the mamos have continued to hold on strongly to their traditional roles and institutions, a significant reason why the Kogui are still able to continue practicing their traditional spiritual, political, and cultural authority and identity. To this day, the Kogui continue to maintain and strongly safeguard their culture, traditions, and identity, with very little interaction with people other than their fellow Indigenous peoples of the Sierra Nevada.

The highly integrated socio-ecological and spiritual-material worlds of the Kogui can be described as highly "resilient", largely explained by the exceptionally sustainable lifeway of the Kogui due to i) their holistic relations in and with nature, ii) their cultural pride, and iii) their intricately intertwined spiritual-political governance system (Pyhälä, forthcoming). When I asked some of my interviewees about what it is that enables them and their peoples to so strongly maintain their culture and identity, even in the face of rapidly growing tourism and encroachment on their lands, the answer I was often given was simply: "well, it is so". Two of the interviewees, both of them male youth in their twenties, said that it is their own choice: "Even I, whenever I get two weeks off from my job [as a tourist guide], I go back to my village".

Another reason for the well-sustained Kogui culture is the fact that education, according to the Kogui, is entirely voluntary, never forced upon children. That said, more and more Kogui children are choosing to go to school, as explained above. "The youth today are not as they used to be", said one concerned Kogui elder in our interview. Similarly, until a few decades ago, everyone's clothes were handmade - the cotton self-grown, then spun, and woven - by the men - in the village. While the Kogui continue to proudly wear their traditional dress of all-white cotton garments, nowadays cotton is no longer as commonly cultivated as it used to be, and very few Kogui continue to spin and weave their own cotton. Instead, they are increasingly opting to purchase ready-fabricated white cotton cloth from the city, of which they sow their clothes. What impacts this has on social organization and gender roles is still unstudied, but an important question to look into.

\section{Views on development}

The Kogui recognize and live according to the intricate interconnectivity amongst and between all human and non-human elements. According to OGT (2017), the Kogui see that the ways in which Western civilization understands what we call "development" imply a tremendous act on the environment in order to get out from "her" all that can be extracted, not only physically but also spiritually. They see that "development" projects that empty territories of their waters, their plants, animals, air, and stones also imply extracting their spiritual fathers and mothers, resulting in a disequilibrium and breaking the harmony of all of the universe. Of all forms of "development", the most destructive are the mega-projects - which cause extinction and/or evacuation of pretty much all life in situ. 
When asked what aspirations they have for future "development" and "sustainability", the Kogui that I interviewed (including youth, elders, mamos, and those working for the resguardo at the OGT) gave pretty much the same set of answers, which I summarize as follows. The absolute number-one priority, even after long discussions during focus groups, was one commonly shared by all the mamos interviewed, namely: the reclamation of Kogui ancestral territory, in order to conserve it better and in order to have full access to all sacred sites therein. In practical terms, this means financial support for the resguardo to buy back these ancestral lands.

The Kogui have already come some way in reclaiming some of their ancestral territory, with the help of the recognition of establishment of the RKMA, through their own efforts, and with the help of national and international organizations. Even the Colombian government has in some instances provided support. To date, the RKMA has been able to purchase back 25,000 hectares, which has helped the resettlement of many Kogui families and communities in their ancestral territory, for their own subsistence as well as to carry out effectively their own processes of nature conservation. In these territories, they have succeeded to regenerate flora and fauna, forests and biodiversity in general, as well as to protect important water sources, re-establishing the natural equilibrium that once was. Such achievements can be seen for instance in the watershed of the Don Diego River, in which during 1995-2001 - in only seven years - a significant forest cover was re-established, based on traditional cultural principles and practices.

The Consejo Territorial de Cabildos Indigenas (CTCI) is responsible for mobilizing the process of reclaiming the Línea Negra, (the Black Line - which connects all the sacred sites along the coast), including the Tayrona NP (CTCI, 2015). Yet, despite the strong will, there are still many unanswered questions about the implications this land recuperation will have, both in political and legal terms. As one employee at OGT stated:

We need more strengthening, capacity building and collaboration from people who understand the situation and can help us plan how to go about this ... We have identified the threats, but now we need to demonstrate and map where these threats are located, and how they are impacting, where and what and who.

(pers. comm.)

Hence, one useful project identified in our discussions with OGT representatives would be to map the entire area of the Linea Negra - using GIS and biodiversity monitoring, including socio-economic and cultural aspects of biodiversity - and to update this information onto the map of the resguardo. In addition, they saw as useful to have a map showing the extension plans of Parques, overlaying the hydrological river basins and water management systems with tourism, conservation, and other impacts. This could be done in collaboration with research on the baseline of what is the current state of the 
environment, incorporating traditional local knowledge, but also forest cover and threats, and one suggestion was to incorporate Kogui youth in carrying out this research using citizen science-type methods.

One OGT representative underscored the importance of an integrated approach. While he said that the priority remains the recuperation of the Kogui sacred sites, he stressed that this should be done involving education, health, territory, and wellbeing, because all knowledge is concentrated in these sacred sites; they are the origin of everything. He said that capacity-building and strengthening (including infrastructure) is needed in all domains: education, healthcare, and territorial rights.

Another interviewee, a Kogui youth who has been involved in many development projects across sectors, shared his views on what he thinks should be the priority projects for the Kogui. In his opinion, the priorities should involve (in no specific order), general awareness-raising and capacity-building on waste management, starting with cleaning up all the garbage in the Sierra (left by tourists), and building awareness on how to reduce garbage in the first place, to replace all mercury batteries and chargers with solar-powered ones, and to replace all plastic consumable wraps with paper, cardboard, or ideally leafwrapped ones. He also stressed the importance of medicinal plant knowledge transmission. This is the domain of ancestral knowledge that is perhaps being lost the fastest. Only a few mamos and mujeres sabias still hold this knowledge, and they remain isolated higher up in the Sierra, meaning this knowledge is not being passed on to younger generations, at least not in the mid- and lowlands. The traditional knowledge and practices around health are further being lost as the villages further down the mountain are increasingly being brought health centres, so when people have an ailment, they go directly to these. One Kogui interviewee stated that there should be a separate and specific project targeted entirely to support the apprenticeship of mamos specialized in medicinal plants. In addition, one mamo said he would like to have support for projects teaching youth to make traditional musical instruments (drums and flutes) and teaching them how to play and sing and dance, as this musical knowledge is also rapidly being lost. He also expressed the will to receive help in transmitting the traditional knowledge of weaving and other handicrafts, but he felt that he cannot do all this alone.

These different domains of traditional knowledge, one Kogui youth said, would be best integrated into the education system, such that children in school learn not only according to a Western curriculum and knowledge and value system, but also as much as possible their own traditional, cultural, and spiritual knowledge, beliefs, and practices. For this, it is important to directly incorporate the wisdom and insights of the mamos. Recent community-led initiatives such as the GEF-SGP project on "Salvaguardia" hold some promise, but they are not the solution. The aim of that project is to integrate the traditional knowledge of each of the four Indigenous peoples in the Sierra into a common plan, in a process by which youth representatives in each of the selected villages undertake a joint reflection together with the community, including with the mamos, 
elders, women, and youth, stimulating a dialogue on how to go about conserving the ancestral knowledge. The idea is to empower the youth and to see what is needed. Still, one mamo's reaction to this was: "who do they [the youth] represent? What are they going to do? How are they ever going to know what the mamos know?" Clearly, the knowledge, wisdom, insight, and power held by the mamos is something that cannot be underestimated. The spiritual legacy that the mamos hold, and the function this has on Kogui life and livelihood and what this represents and means to them, is perhaps what is most important, yet is most often overlooked in externally initiated projects. Similarly, one interviewee stressed that women are the key for maintaining culture, and in order for projects to succeed, we need make sure we work with the women. Also, much care needs to be taken in terms of the process of how projects are designed, communicated, planned, and implemented, with one interviewee stressing the importance of dialogue that involves all four Indigenous peoples in the Sierra, and hearing all of their views.

In terms of livelihood strategies, there are several potential economic alternatives that the Kogui could pursue, such as cultivation and commercialization of wild coffee, cacao, malanga (a root vegetable), maize, traditional seeds, and native tree species. Wild coffee is an excellent alternative as it has large global demand, but does not replace or displace food grown for nutritional purposes (i.e., like what has happened with quinoa and other traditional health foods that are no longer consumed locally because they are too expensive). Another suggestion given by the mamos interviewed including support in the commercialization of handicrafts. Ideally, the Kogui would most like to continue maintaining their traditional diversified livelihoods - each sustaining the other - incorporated into local knowledge transmission and exchange. As one representative at OGT summed up, for Indigenous self-determination, you need all three of the following determinants: i) autonomy, ii) sovereignty, and iii) security. This applies to all sectors, be it food, knowledge and education, healthcare, or natural resource management. The priority of the official governing body of the Kogui (OGT), in addition to reclaiming back their ancestral land, is to reclaim and strengthen Kogui culture and governance.

What is clear from all the above suggestions and priorities given by the Kogui representatives interviewed is the need to a) restore rights and access to ancestral territory, particularly sacred sites, and b) promote the revitalization of traditional knowledge, supporting the existing knowledge holders, both men and women, and recuperate their rightful spaces and institutions. The latter could be done in inspiration by the work that for instance CEMI has carried out with Indigenous peoples elsewhere in Colombia, initiating communitydesigned "Planes deVida" (Life Plans) rather than an externally defined "development plan". Such a Life Plan is based on the peoples' own reflections on their own values - locally and culturally defined - rather than on values imposed or imported from a society or culture outside. Also, recognizing the local and place-based "Ley de Origen" - their own knowledge and customary law - is crucial for defining the most appropriate governance mechanisms. The sharing 
of these does not necessarily need to be in written format (as us Westerners tend to automatically assume), but also (or rather) in oral transmission and storytelling - which can well be incorporated into both informal interaction as well as schooling (for inspirations of such approaches, see for examples CEMI, 2014).

\section{Kogui rights to territory, culture, autonomy, and self-governance}

The Kogui, with the help of a handful of national and international NGOs, are now trying to reclaim their ancestral territory. And according to international law - i.e., the International Labour Organisation's Convention 169 and the United Nations Declaration on the Rights of Indigenous Peoples - they have every right to do so. These and other forms of international conventions and agreements underscore Indigenous rights to ancestral territory and their own customary law. Despite these international legal agreements, the Colombian state continues to turn a blind eye to many of the - even illegal - impositions of economic "development" in the SNSM, disregarding the region's Indigenous peoples' rights to self-determination. Meanwhile, as illustrated above with a number of examples, there is an incoherence between the rules and regulations of the state (and in all its manifestation across policies, planning, programs, projects, and investments), on the one hand, and the traditional form of biocultural governance of the Kogui, on the other.

The discrepancy between public policies and Indigenous self-determination can be seen in the way that large and environmentally destructive development projects are licensed (even on top of sacred sites), whilst state-run biodiversity and conservation projects prioritize tourism over Indigenous rights. Indeed, the entire land-use planning scheme of the SNSM is currently driven based on Western formats of land entitlement, privatization, and commodified use of natural resources, instead of emerging from and being based on traditional forms of land and natural resource management. The imposed economic development prioritizes a vision based on Western economic development, monetization, and employment, capitalizing on the wealth of resources still available in the area, but severely compromising the culture and wellbeing of the Kogui and other Indigenous peoples of the Sierra. These external investors have prioritized economic interests over any impact that these are clearly having in the area with respect to the environment, the Indigenous peoples, and their ancestral territory, thus overlooking national and international human rights law. Those actors planning and imposing "development" in the area lack the knowledge and understanding of the principles by which the actual owners of the territory - the Indigenous peoples - have for generations managed their own autonomy, territory, and society.

This incoherence, superimposition, and lack of understanding on the part of external actors inevitably leads to an inherent contradiction in terms. Even mechanisms of free, prior and informed consent (FPIC) and other forms of 
consultation have been misused, seeing that they have been applied to legitimize the actions and decisions of external actors, rather than guaranteeing the fundamental rights of the Indigenous peoples, as is their actual purpose. The Colombian state has failed to facilitate any intercultural dialogue, consultation, deliberative processes of dialogue, or other rights-based approaches.

The Kogui, despite these challenges, continue to practice their own form of self-governance based on the Law of Origin (see Witte 2018), which has principles of order established and developed according to the sacred spaces, as well as the spaces administered by their own authorities, the mamo, and the authorities of the community, the júgukwi. The Law of Origin tells them how they should educate their children and organize themselves as a community, what they should and should not do, how to resolve problems and disorder, how to give offerings, how to heal nature when they have not complied with the norms. The knowledge of, and compliance with, the Law of Origin is overseen by the mamos, the highest-ranked spiritual leaders and the principal knowledgeholders amongst the Kogui. One chief mamo told me that the mamos, too, need support to keep doing the work they do, particularly in the continued training of apprentices. The apprentices and their families need support - in the form of clothes, mochilas (bags), food, and other necessities. While the apprentices are learning to become mamos (rather than helping their families in the cultivation, harvesting, hunting, and other livelihood activities), the families need support. Back in the days, the entire community would contribute. They would bring food, clothes, and other donations to the apprentices and their families. This is no longer the case, and there are fewer and fewer apprentices carrying on with the training, sometimes none. "If we had this community support then I would have young boys here now learning with me", said one mamo, who expressed his concern for the broken transmission of this age-old wisdom.

Externally, the Kogui are represented by one governing chief, the Cabildo Gobernador (Chief Governor), based at the Organisación Gonawindua Tayrona (OGT). OGT is the most prominent organization representing and working on Kogui rights to self-determination and territory and is the main representative body of the Indigenous peoples in the Sierra Nevada. According to one of the OGT representatives interviewed, the organization focuses its work on "regenerating and recovering the ancestral territory, and to do this in a cultural manner" (pers. comm., 2018). Despite their close cultural and historical proximity and interwoven social relations, there are some political tensions between the four Indigenous peoples of the Sierra Nevada. For instance, there are some jealousies on the part of some Wiwa representatives with regards to the Kogui. One of the reasons for this tension is that the Cabildo Gobernador is always a Kogui, for historical reasons, seeing as the resguardo is traditionally Kogui territory. From the Kogui perspective, these tensions stem from the rumor of a Wiwa leader wanting to place himself as the next Cabildo Gobernador of the resguardo, a position that has always belonged to the Kogui. There are also political disagreements and tensions amongst the Kogui themselves. Of the 49 Kogui communities in the resguardo, 42 communities are officially members 


\section{Aili Pyhälä}

of OGT, while seven communities have withheld, for political reasons. One mamo interviewed said that the problem is that OGT no longer represents all the Kogui. Many of these tensions relate to disagreements on whether or not to allow tourism in the resguardo, a highly contentious and delicate issue that is still being debated, as has been detailed above.

\section{Recommendations}

Based on the above priorities and demands voiced by the Kogui, I outline below some recommendations as to how external actors could either take action or disengage to best support the Kogui, rather than continuing with assumptions and impositions of externally driven and defined development programs that may in fact be causing more harm than good to the biocultural sustainability of the Sierra Nevada.

The fact that the Sierra Nevada remains as ecologically intact as it is, even after multiple generations of inhabitancy by the Kogui and other Indigenous peoples, goes to show that the local management of natural resources and community-conservation has worked for generations, and continues to be effective. There are even several cases of the Indigenous peoples of the Sierra reclaiming degraded pockets of their ancestral territory in the foothills, and within a decade, these reclaimed areas are already thriving with biodiversity (pers. comm., National Parks representative). Several studies elsewhere are now coming to the same conclusions - i.e., to acknowledge the importance of Indigenous territories in terms of their conservation value (Ross et al., 2011; Garnett et al., 2018). Therefore, contrary to compromised modes of collaboration as suggested by Lin and Liu (2016), I argue that the ancestral territory of the Kogui be handed over to the full governance of the local Indigenous peoples in the form of an ICCA (a territory conserved by Indigenous peoples and local communities) or other effective conservation mechanism.

In terms of getting assistance in reclaiming and getting back their ancestral territory, the Amazon Conservation Team (ACT) has already helped the Kogui purchase back some of their ancestral land, in collaboration with the Tayrona Heritage Trust (THT, set up by Alan Ereira) and Tchendukua (a French NGO) (THT 2008; ACT 2017; Tchendukua - Ici et Ailleurs 2017). Yet only a fraction of the ancestral territory has been recuperated, and the Kogui are calling out to anyone willing to help them purchase back their land so that they can better care for it and continue with their spiritual practices, particularly with their offerings at sacred sites.

For the Indigenous peoples of the Sierra to be better able to claim and communicate their biocultural rights, locally led knowledge and resource-mapping processes such as biocultural protocols (BCPs) (see Bavikatte and Jonas, 2009), Indigenous-led codes of ethical conduct (e.g., using Akwe: Kon Guidelines; see CBD 2004), and tools for dialogue (e.g., with the help of the Whakatane Mechanism (2018)) would be important. Such processes would help ensure 
the full and effective involvement of local Indigenous rights-holders in all dialogues concerning them and their territory. With regards to tourism, seeing that the large majority of Kogui communities in the resguardo oppose tourism, steps should be taken to at least avoid any further expansion of tourism in the area, both in terms of quantity and extension, whilst negotiations are underway about whether tourism should even be allowed in the resguardo in the first place. Key to this is setting and adhering to the carrying capacity according to carefully defined limits based on local knowledge and ecological and socio-cultural values in those areas impacted in one way or another by tourism.

Meanwhile, sustainable locally based healthcare calls for an urgent restoration and revival of the traditional knowledge - and its sustained transmission on health, provision, and healing agents (including medicinal plants), whilst ensuring that there are at least a handful of doctors in Western medical centres that are of Kogui (and other local Indigenous) origin, to allow for healthcare in native languages. In terms of education, the sporadic one-off visit of a few mamos to a handful of schools once a year - as is currently the case - is not enough to maintain the wealth, depth, and richness of traditional knowledge and beliefs. For Kogui culture and cosmovision to persist, it needs to be integrated much more holistically and thoroughly into the entire schooling system and curriculum. These elements of "development" cannot and should not be treated apart or separately, as has been found to be the case also elsewhere. For instance, ethnobotanical knowledge in Indigenous societies has been found to be significantly associated with child health (McDade et al., 2007). In terms of governance, the knowledge, skills, and beliefs along traditional practices, territory, health and medicinal plant use, knowledge of native plant and animal species, small-scale cultivation techniques, and reverence to what is sacred and in aluna, needs to be returned to locally governed management and transmission along the asuanos.

\section{Conclusions}

As this chapter illustrates, decades of colonization, domination, and imposition under arguments of economic development have had negative impacts on the socio-economic, cultural, spiritual, and political integrity of the Kogui and other Indigenous peoples of the Sierra Nevada, putting their autonomy, traditional knowledge, and wellbeing at risk. The rights of the Indigenous peoples of the Sierra to live in autonomy and self-govern their territory has in fact not been taken into account in the planning of so-called development; on the contrary, many of the mega-projects and tourist hotspots have been installed on top of primary sacred sites, violating their spiritual, cultural, and material significance.

It is remarkable that despite the extent of external interventions, the Kogui continue to maintain their culture and identity. This is enabled largely by their continued voluntary isolation, self-governance according to their own overarching nature-based cosmovision, strong-held culture and identity, and a highly egalitarian and effective system of spiritual leadership.Yet, the external pressures 


\section{Aili Pyhälä}

of so-called "development" in the forms of extractivist mega-projects, assimilation, and tourism are not likely to cease anytime soon; if anything, they may take a turn for the worse. What, then, is needed for Indigenous self-determination and long-term sustainability in the Sierra Nevada de Santa Marta? How can the Kogui be enabled and supported in gaining access and rights over their ancestral territory? What can be done to help the Kogui revitalize their social, cultural, spiritual, political, and economic identity, knowledge, and livelihood practices that are being rapidly lost? What should be done about the rapidly growing tourism, extension of protected areas, infiltration by Western healthcare and education, and other (often destructive) development interventions?

Essentially, the Kogui want to regain their ancestral land and just want to be left in peace. That said, at least those Kogui mamos and representatives that I spoke to are willing to receive support to realize these and other rights. Key to this is to support Kogui authorities to serve their functions in accordance with their own structure of social organization, based on their own principles of ezuama and nikuma. Rather than imposing external modes of governance, representation and knowledge transfer, the outside world should simply allow and support the Kogui to revitalize the traditional practices to comply with their own mandate of the Law of Origin, which they believe is necessary to reestablish the social and natural order. Moreover, external institutions should act accordingly to allow the Kogui to re-gain their own autonomous management over their own territory, as well as their own spaces and forms of governance, re-affirming the cultural identity in children and youth with the help of their own traditional learning and livelihood (including food production) systems.

Seeing that all these domains - territory, spirituality, culture, and knowledge are in the Kogui case intricately interwoven and interconnected, it is difficult (if not inappropriate) to decide what is priority or most urgent. In fact, the very interconnectedness should determine the approach, whilst always remembering that what may seem to "make sense" according to the Western mind frame and externally defined "development checklist" may simply not work in the context of the Sierra Nevada and its Indigenous peoples. The intention with this chapter has been to provide some updated information and insights - based on recent interviews in situ - as to where to prioritize future efforts, which I hope have helped answer (or at least better inform) some of the above posed questions and challenges. I believe that Indigenous peoples and local communities across the globe could get a great deal of inspiration from the Kogui in terms of considering alternatives to development, whilst maintaining culture, identity, and socio-environmental sustainability. Supporting the Kogui and other Indigenous peoples of the Sierra Nevada to reclaim their territorial rights and self-determination, and facilitating processes of sharing and exchange with communities elsewhere, is something us outsiders can help to do. Meanwhile, there are many aspects that we have lost in our modern path of development that we now - in our desperate need to redirect our own path toward a sustainable one - could do well in listening to and learning from our older Indigenous brothers and sisters. 


\section{Acknowledgments}

I would like to give my sincere thanks to both FINCEAL+ and CICADA for funding my field visits. My deepest gratitude goes to Daniel Garavito and Lorenzo Malo, both of whom served as my translators, for their invaluable support and assistance not only during my interviews and focus groups, but throughout my fieldwork. I would also like to give heartfelt thanks to Carolina Amaya and German Zuluaga for highly inspirational conversations, their warm hospitality in Bogota, and for connecting me to OGT. Profound thanks also to Mauricio Blanco for all his logistical support, for being so generous with his time and availability, and for all the long, informative, and emotional conversations. Last but not least, heartfelt thanks to Antonio Briceño, whose work and friendship led me to the Sierra Nevada.

\section{References}

Altman, J.C. and Kerins, S. 2012. People on Country, Vital Landscapes, Indigenous Futures. Sydney: Federation Press.

Aluna the Movie. 2011. Aluna - There is No Life without Thought [online]. Available at: www.alunathemovie.com/en [accessed 2018].

Amazon Conservation Team. 2017. Water, Wildlife and Hope: Rejuvenating a Kogi Sacred Site [online]. Available at: www.amazonteam.org/water-wildlife-and-hoperejuvenating-kogi-sacred-site [Accessed August 2018].

Arbeláez Albornoz, C. 1994. 1997. El lenguaje de las burbujas: Apuntes sobre la cultura médica tradicional entre los Kogui de la Sierra Nevada de Santa Marta. In A. Colajanni (ed.), El pueblo de la montaña sagrada. Tradición y cambio, 149-172. La Paz, Bolivia: Gente Común.

Bavikatte, K. and Jonas, H. 2009. Biocultural Community Protocols: A Community Approach to Ensuring the Integrity of Environmental Law and Policy. Nairobi and Cape Town: UNEP and Natural Justice.

Berkes, F. 1999. Sacred Ecology: Traditional Ecological Knowledge and Resource Management. London: Taylor \& Francis.

Briceño, A. 2007. Gods of America: Natural Pantheon. Orinoco y Amazonas Editores. Venezuela: Caracas.

CBD. 2004. Akwé: Kon Voluntary Guidelines for the Conduct of Cultural, Environmental and Social Impact Assessment Regarding Developments Proposed to Take Place on, or Which Are Likely to Impact on, Sacred Sites and on Lands and Waters Traditionally Occupied or Used by Indigenous and Local Communities (Secretariat of The Convention on Biological Diversity, Montreal, 2004).

CEMI. 2014. Gestores Legales Interculturales: La ley es de origen. Centro de Estudios Medicos Interculturales. Bogota: CEMI.

Corntassel, J. 2008. Toward Sustainable Self-Determination: Rethinking the Contemporary Indigenous Rights Discourse. Alternatives, 33: 105-132.

Corntassel,J. and Bryce, C. 2012. Practicing Sustainable Self-Determination: Indigenous Approaches to Cultural Restoration and Revitalization. Brown Journal of World Affairs, XVIII (11): 151-162. 
CTCI (Consejo Territorial de Cabildos Indigenas de la Sierra Nevada de Santa Marta). 2015. Documento Madre de la Linea Negra - Jaba Séshizha- de los cuatro pueblos indígenas de la Sierra Nevada de Santa Marta. Convenio TDTG-SCTO 24-210-05-15.

de la Cadena, M. 2011. Earth Beings: Ecologies of Practice Across Andean Worlds. Durham, NC and London: Duke University Press.

Ereira, A. 1992. The Elder Brothers. New York: Knopf.

From the Heart of the World. 1990. [Film] Directed by Alan Ereira. BBC.

Garnett, S.T., Burgess, N.D., Fa, J.E., Fernandez-Llamazares, A., Molnar, Z., Robinson, C.J., Leiper, I. et al. 2018. A Spatial Overview of the Global Importance of Indigenous Lands for Conservation. Nature Sustainability, 1(7), 369-374.

Gudynas, E. 2017. Post-Development and Other Critiques of the Roots of Development. In H.Veltmeyer and P. Bowles (eds), The Essential Guide to Critical Development Studies, pp. 84-93. New York: Taylor \& Francis.

Heinrich, J., Heine S.J., and Norenzajan, A. 2010. The Weirdest People in the World? Behavioral and Brain Sciences, 33: 61-135.

Johnson, J.T., Howitt, R., Cajete, G., Berkes, F., Louis, R.P., and Kliskey, A. 2016.Weaving Indigenous and Sustainability Sciences to Diversify our Methods. Sustainability Science, 11: 1-11.

Kohn, E. 2013. How Forests Think: Toward an Anthropology Beyond the Human. Berkeley, CA: University of California Press.

Lin, P.-S.S. and Liu, Y.-L. 2016. Niching Sustainability in an Indigenous Community: Protected Areas, Autonomous Initiatives, and Negotiating Power in Natural Resource Management. Sustainability Science, 11: 103-113.

Lindroth, M. and Sinevaara-Niskanen, H. 2015. The Biopolitics of Resilient Indigeneity and the Radical Gamble of Resistance. Resilience. DOI: 10.1080/ 21693293.2015.1094243.

McCarter, J., Gavin, M.C., Baereleo, S., and Love, M. 2014. The Challenges of Maintaining Indigenous Ecological Knowledge. Ecology and Society, 19(3): 39.

McDade, T.W., Reyes-Garcia, V., Blackinton, P., Tanner, S., Huanca, T., and Leonard, W.R. 2007. Ethnobotanical Knowledge is Associated with Indices of Child Health in the Bolivian Amazon. Proceedings of the National Academy of Sciences of the United States of America, 104(15): 6134-6139.

OGT. 2017. La Organización, Pueblo Kággaba, Territorio Ancestral. Afectaciones. Nuestro trabajo. Website of the Organisación Gonawindúa Tayrona: Available at: https://gonawindua.org/ [Accessed August 2018].

Orrantia, J.C. 2002. Matices Kogi: Representaciones y negociación en la marginalidad. Revista Colombiana de Antropología, 38: 54-75.

Ortiz Ricaurte, C. 2004. Resistencia y procesos de integración indígenas: El caso de los Kogui de la Sierra Nevada. Boletin Antropológico, 22(60): 73-88.

Reichel-Dolmatoff, G. 1950. Los Kogi: Una tribu indígena de la Sierra Nevada de Santa Marta, Colombia. Tomo 1. Revista del Instituto Etnológico Nacional (Bogotá), 4 (1-2): 1-319.

Reichel-Dolmatoff, G. 1976. Training for the Priesthood among the Kogi of Colombia. In J. Willbert (ed.), Enculturation in Latin America: An Anthology, pp. 265-288. Los Angeles, CA: Latin American Center, University of California.

Reichel-Dolmatoff, G. 1982. Cultural Change and Environmental Awareness: A Case Study of the Sierra Nevada de Santa Marta. Mountain Research and Development, 2(3): 289-298. 
Reichel-Dolmatoff, G. 1987. The Great Mother and the Kogi Universe: A Concise Overview. Journal of Latin American Lore, 13(1): 73-113.

Rodriguez-Navarro, G.E. 2000. Indigenous Knowledge as an Innovative Contribution to the Sustainable Development of the Sierra Nevada de Santa Marta, Colombia: The Elder Brothers, Guardians of the "Heart of the World". Ambio, 29(7): 455-458.

Ross, A., Pickering Sherman, K., Snodgrass, J.G., Delcore, H.D., and Sherman, R. 2011. Indigenous Peoples and the Collaborative Stewardship of Nature: Knowledge Binds and Institutional Conflicts. Walnut Creek, CA: Left Coast Press.

Tairona Heritage Trust (THT). 2008. Tairona History and Tairona Culture [online]. Available at: http://tairona.myzen.co.uk/index.php [Accessed August 2018].

Tchendukua - Ici et Ailleurs. 2017. Les peuples de la Sierra [Online]. Available at: www. tchendukua.org [Accessed August 2018].

Uribe, C. 1998. Un relato de encuentros y desencuentros: La sociedad y el poder entre los Hermanos Mayores de la Sierra Nevada de Santa Marta. In María Lucía Sotomayor (ed.), Modernidad, Identidad y Desarrollo Construcción de Sociedad y Recreación Cultural en Contextos de Modernización, pp. 73-83. Bogota: Instituto Colombiano de Antropología e Historia.

Whakatane Mechanism. 2018. About. Available at: http://whakatane-mechanism.org [Accessed August 2018].

Witte, F.X.P. 2018. Living the Law of Origin: The Cosmological, Ontological, Epistemological and Ecological Framework of Kogi Environmental Politics. PhD dissertation submitted for the degree of Doctor of Philosophy in Social Anthropology, University of Cambridge. 